\title{
Compressive Creep Testing of Composites on the Based of MoSi 2 - SiC Nanoparticles
}

\author{
Natália Luptáková ${ }^{1,2}$, Beáta Ballógová3 ${ }^{3}$ Petr Dymáček ${ }^{1,2}$ \\ ${ }^{1}$ CEITEC-IPM, Žižkova 22, 61662 Brno, Czech Republic. E-mail: luptakova@ipm.cz \\ ${ }^{2}$ Institute of Physics of Materials, Academy of Sciences of the Czech Republic, Žižkova 22, 61662 Brno, Czech Republic. \\ E-mail: pdymacek@ipm.cz \\ ${ }^{3}$ Institute of Materials Research of Slovak Academy of Sciences, Watsonova 47, 04001 Košice, Slovak Republic, E-mail: \\ bballokova@imr.saske.sk
}

The aim of this study is to investigate the creep resistance of molybdenum disilicide (MoSiz-SiC) based composites with different types of embedded particles. The materials were prepared via powder metallurgy using high temperature controlled reaction sintering (CRS). The creep experiments were performed in uniaxial compression at constant stress in the temperature range from $1273 \mathrm{~K}\left(1000^{\circ} \mathrm{C}\right)$ to $1473 \mathrm{~K}\left(1200{ }^{\circ} \mathrm{C}\right)$ for applied stress from 50 to 100 MPa. Creep was tested by stepwise loading: in each step, the load was changed to a new value after steady state creep rate had been established. The applied stress dependences of the creep rate at different temperatures were analyzed in terms of stress exponent $(n)$ and activation energy $(Q)$. Possible rate-controlling mechanisms were suggested.

Keywords: $\mathrm{MoSi}_{2}-\mathrm{SiC}$, creep test, compressive creep, stress exponent, activation energy

\section{Acknowledgement}

This work was realized in CEITEC - Central European Institute of Technology with research infrastructure supported by the project CZ.1.05/1.1.00/02.0068 financed from European Regional Development Fund.

\section{Refereces}

[1] AJAYAN, P. M., SCHADLER, L. S., BRAUN, P. V. (2003). Nanocomposite Science and Technology, pp. 68 69. Wiley-VCH, Weinheim.

[2] PETROVIC, J. J. (1995). Mechanical behavior of $\mathrm{MoSi}_{2}$ and $\mathrm{MoSi}_{2}$ composites. In: Materials Science and Engineering $A$, Vol. 192-193, No. 1, pp. $31-37$.

[3] MARKOVICOVA, L., HURTALOVA, L., ZATKALIKOVA, V., GARBACZ, T. (2014). Evaluation of composite structures by light microscopy and image analysis. In: Manufacturing Technology. Vol. 14, No. 3, pp. 351-355.

[4] VALÁŠEK, P., MÜLLER, M. (2014). Picture analysis of failure areas of particle composites. In: Manufacturing Technology. Vol. 14, No. 3, pp. 474-478.

[5] BALLÓKOVÁ, B., BESTERCI, M., HVIZDOŠ, P. (2009). High temperature properties of the MoSi ${ }_{2}$ and $\mathrm{MoSi}_{2}-$ SiC nanocomposites. In: High temperature materials and progress. Vol. 28, No. 5, pp. 271 - 276.

[6] SCHOLL, R., KIEBACK, B. Patent DE 4418598 A1.

[7] BALLÓKOVÁ, B. (2008). Štruktúra a mechanické vlastnosti kompozitov na báze MoSi $i_{2}$ PhD Thesis. [In Slovak], p. 98. ÚMV SAV, Košice.

[8] SADANANDA, K., FENG, J., JONES, H., PETROVIC, J.J. (1992). Creep of molybdenum disilicide composites. In: Mater. Science and Eng. A. Vol. 155, pp. $227-239$.

[9] SADANANDA, K., JONES, H., J FENG, J., PETROVIC, J.J., VASUDEVAN, A.K. (1991). Creep of monolithic and $\mathrm{SiC}$ whisker-reinforced $\mathrm{MoSi}_{2}$, In: Ceram. Eng. Sci. Proc. Vol. 12, No. 9 - 10, pp. 1671 - 1678.

[10] ČADEK, J. (1988). Creep in metallic materials, pp. 205 - 209. Academia Prague, Prague

[11] KOFSTAD, P. (1966). High Temperature Oxidation of Metals, John Wiley \& Sons, New York. 